\title{
Importance Performance Analysis of Factors Causing Reworks in the Construction Industry
}

\author{
Andi $^{*}$, Rahardjo, J.1, and Fendy ${ }^{2}$
}

\begin{abstract}
Rework can bring negative effect to construction project. This research aims to identify the importance level of factors causing reworks in structural, finishing, and mechanical, electrical and plumbing (MEP) works by a way of importance performance analysis (IPA). In order to reach this objective, the research evaluates the degree of occurrence the factors in each type of works and analyzes the level of difficulty in preventing the occurrence of the factors. The results are based on questionnaire survey, involving general and MEP contractors in Surabaya. Design related factors are the most frequent and most difficult to prevent in structural and finishing works. In MEP works, the most frequent factors are tight construction duration and unclear instructions from owner and designer; whilst insufficient owner's capital is the most difficult to prevent. The research finds two factors that have high importance level, i.e. design changes and insufficient detail drawings.
\end{abstract}

Keywords: Importance performance analysis; rework; project construction.

\section{Introduction}

Rework cannot be avoided in all construction projects. The occurrence of rework can cause many impacts on construction work in terms of productivity, time, and cost. Burati et al. [1] and Barber et al. [2] revealed that the costs arising from the emergence of rework are up to $20 \%$ of the contract value. In addition, the cost required to fix quality problems is $12.4 \%$ of the contract value [1]. More recent studies also state that the direct costs arising from the rework are $15 \%$ of the contract value [3] and $10 \%$ of the contract value of infrastructure projects [4].

Zhang et al. [5] note that reducing rework on construction projects is seen as an effective way to increase development in terms of productivity, cost and time. By knowing which causal factors are important, it is hoped that the appearance of rework can be reduced or even eliminated in construction work. Several studies have been conducted to determine the factors causing the rework [6-8]. however, this research is general or not specific for structural, finishing, and mechanical, electrical and plumbing (MEP) works. It is argued that frequent factors causing specific construction work may be different. This will be elaborated in this current paper.

${ }^{1}$ Postgraduate Program in Civil Engineering, Petra Christian University, Surabaya, INDONESIA

${ }_{2}^{2}$ PT. Sutandi Jaya Sejahtera, Surabaya, INDONESIA

*Corresponding author; Email: andi@petra.ac.id

Note: Discussion is expected before November, $1^{\text {st }} 2020$, and will be published in the "Civil Engineering Dimension", volume 23, number 1, March 2021.

Received 20 August 2020; revised 27 August 2020; accepted 31 August 2020
After knowing which factors frequently occur, it is then important to understand how to manage and prevent them. The more difficult to prevent the factors from occurring, the more important the factors are. Researches on the factors causing rework so far have never been carried out to see the difficulty level of prevention.

Based on this background, this study aims to determine the importance level of factors causing reworks on the structure, finishing, and MEP works from the contractor's point of view by a way of importance performance analysis (IPA). The analysis will simultaneously consider the frequency of occurrence of the rework and the level of difficulty in preventing of each factor in each construction work.

\section{Literature Review}

\section{Definition}

CIDA [9] and Love [10] define reworks as unnecessary impact of repeating a process or activity that was done incorrectly the first time, which can be caused by errors or variations. It is activity that must be done more than once or activity that removes work previously done as part of the project [11]. Taylor [12] adds that changes may occur either through errors, omissions or regulatory changes.

In line with the previous study [6], in this paper rework is defined as an activity in the field that must be done more than once, or an activity that eliminates work that has been done previously as part of a project. This definition is considered to be the most appropriate because it includes a limitation for the occurrence of a rework described previously [6]. 


\section{Factors Causing Reworks}

Table 1 shows the factors causing the rework taken from several sources [5,6,13-16]. These factors are grouped into 9 categories based on their type and characteristic, namely design and documentation factors, planning and scheduling factors, material and equipment factors, human resource factors, leadership and communication factors, instruction and inspection factors, external environmental factors, and contract administration factors.

Table 1. Factors Causing Rework

\begin{tabular}{|c|c|c|c|c|c|c|c|c|c|}
\hline \multirow{2}{*}{ No } & \multirow{2}{*}{ Factors } & \multicolumn{4}{|c|}{ Frequency } & \multicolumn{4}{|c|}{ Difficulty Level of Prevention } \\
\hline & & Structural & Finishing & $M E P$ & P-Value & Structural & Finishing & $M E P$ & P-Value \\
\hline & Design and documentation & & & & & & & & \\
\hline 1 & Design changes & 4.38 & 4.38 & 3.38 & $0.006^{*}$ & 3.88 & 4.11 & 3.75 & 0.473 \\
\hline 2 & Unclear detail drawings & 4.09 & 4.14 & 3.00 & $0.002^{*}$ & 3.68 & 3.88 & 2.56 & $0.001^{*}$ \\
\hline 3 & Lack of constructability aspects & 3.48 & 3.70 & 2.81 & $0.029 *$ & 3.30 & 3.48 & 2.94 & 0.288 \\
\hline 4 & $\begin{array}{l}\text { Lack of consultant's knowledge of } \\
\text { material character }\end{array}$ & 3.70 & 3.75 & 3.06 & 0.205 & 3.34 & 3.38 & 3.56 & 0.838 \\
\hline 5 & Design error & 3.34 & 3.64 & 3.44 & 0.503 & 3.46 & 3.59 & 3.31 & 0.745 \\
\hline & Planning and scheduling & & & & & & & & \\
\hline 6 & Tight project schedule & 3.59 & 3.29 & 3.75 & 0.273 & 3.21 & 3.20 & 3.38 & 0.875 \\
\hline 7 & Lack of working capital from owner & 2.98 & 2.96 & 2.88 & 0.959 & 3.20 & 2.93 & 4.06 & $0.042^{*}$ \\
\hline 8 & $\begin{array}{l}\text { Change in project function } \\
\text { Materials and equipment }\end{array}$ & 2.68 & 2.89 & 1.75 & $0.013^{*}$ & 2.80 & 2.88 & 2.63 & 0.787 \\
\hline 9 & Defective material & 2.95 & 3.29 & 2.00 & $0.001^{*}$ & 2.95 & 3.32 & 2.81 & 0.202 \\
\hline 10 & Material sent incorrectly & 2.46 & 2.80 & 2.75 & 0.280 & 2.54 & 2.88 & 2.19 & 0.086 \\
\hline 11 & Late material & 3.27 & 3.21 & 3.19 & 0.958 & 2.93 & 3.02 & 3.25 & 0.622 \\
\hline 12 & Unavailable when needed & 2.84 & 2.96 & 2.81 & 0.833 & 2.68 & 2.70 & 2.75 & 0.977 \\
\hline 13 & $\begin{array}{l}\text { Material / equipment changes during } \\
\text { construction }\end{array}$ & 3.14 & 3.18 & 3.25 & 0.952 & 2.91 & 3.11 & 3.38 & 0.327 \\
\hline 14 & $\begin{array}{l}\text { Lack of adequate equipment } \\
\text { Human Resources }\end{array}$ & 2.48 & 2.75 & 2.81 & 0.421 & 2.59 & 2.80 & 3.44 & $0.048^{*}$ \\
\hline 15 & Lack of training for workers & 2.61 & 2.71 & 3.31 & 0.075 & 2.45 & 2.63 & 3.44 & $0.010^{*}$ \\
\hline 16 & Lack of workers motivation & 2.73 & 2.66 & 2.88 & 0.830 & 2.84 & 2.64 & 3.19 & 0.300 \\
\hline 17 & Inexperienced workers & 2.71 & 2.68 & 3.00 & 0.658 & 2.84 & 2.71 & 3.50 & 0.098 \\
\hline 18 & The amount of overtime work & 3.70 & 3.23 & 2.81 & $0.026^{*}$ & 3.07 & 2.88 & 3.25 & 0.457 \\
\hline 19 & Wrong work procedure & 2.61 & 2.96 & 2.94 & 0.247 & 2.96 & 2.89 & 2.94 & 0.957 \\
\hline 20 & Worker's errors and omissions & 2.95 & 2.93 & 2.44 & 0.300 & 3.04 & 2.98 & 3.06 & 0.961 \\
\hline 21 & $\begin{array}{l}\text { Leadership and communication } \\
\text { Ineffective communication between the } \\
\text { supervisory consultant and the } \\
\text { contractor }\end{array}$ & 3.54 & 3.18 & 2.75 & 0.083 & 3.52 & 3.21 & 3.31 & 0.455 \\
\hline 22 & $\begin{array}{l}\text { Ineffective communication between } \\
\text { contractors and workers }\end{array}$ & 2.88 & 2.91 & 2.81 & 0.096 & 2.84 & 2.84 & 3.00 & 0.875 \\
\hline 23 & Poor coordination between contractors & 2.84 & 2.89 & 3.44 & 0.208 & 3.04 & 3.00 & 3.69 & 0.075 \\
\hline 24 & $\begin{array}{l}\text { The number of subcontractors / DCs / } \\
\text { contractors involved in the project }\end{array}$ & 3.96 & 3.73 & 3.13 & 0.051 & 3.66 & 3.46 & 3.00 & 0.165 \\
\hline 25 & $\begin{array}{l}\text { Poor decision making process from } \\
\text { contractors }\end{array}$ & 2.57 & 2.98 & 2.75 & 0.228 & 2.86 & 2.71 & 3.06 & 0.535 \\
\hline 26 & $\begin{array}{l}\text { Poor decision making process from the } \\
\text { owner }\end{array}$ & 3.32 & 3.23 & 3.13 & 0.859 & 3.54 & 3.43 & 3.50 & 0.910 \\
\hline 27 & Lack of field information & 2.95 & 3.21 & 2.81 & 0.309 & 2.82 & 2.96 & 3.19 & 0.540 \\
\hline 28 & $\begin{array}{l}\text { Lack of contractor management from } \\
\text { the project team }\end{array}$ & 2.75 & 2.80 & 3.06 & 0.667 & 2.84 & 2.61 & 3.13 & 0.226 \\
\hline 29 & Lack of owner role during construction & 2.91 & 2.88 & 3.38 & 0.952 & 2.91 & 3.11 & 3.38 & 0.603 \\
\hline 30 & Lack of contractor QC commitment & 2.64 & 2.79 & 2.94 & 0.593 & 2.64 & 2.80 & 2.88 & 0.647 \\
\hline
\end{tabular}


Table 1. Continued

\begin{tabular}{|c|c|c|c|c|c|c|c|c|c|}
\hline \multirow{2}{*}{ No } & \multirow{2}{*}{ Factors } & \multicolumn{4}{|c|}{ Frequency } & \multicolumn{4}{|c|}{ Difficulty Level of Prevention } \\
\hline & & Structural & Finishing & $M E P$ & P-Value & Structural & Finishing & $M E P$ & P-Value \\
\hline & Instructions and Inspections & & & & & & & & \\
\hline 31 & $\begin{array}{l}\text { Poor monitoring and control by } \\
\text { contractor }\end{array}$ & 2.55 & 2.86 & 2.81 & 0.366 & 2.64 & 2.61 & 2.94 & 0.624 \\
\hline 32 & $\begin{array}{l}\text { Poor monitoring and control by } \\
\text { consultant }\end{array}$ & 3.04 & 2.95 & 3.38 & 0.574 & 3.18 & 3.14 & 3.00 & 0.901 \\
\hline 33 & $\begin{array}{l}\text { Unclear instructions from the planning } \\
\text { consultant }\end{array}$ & 3.34 & 3.27 & 3.63 & 0.681 & 3.30 & 3.25 & 2.88 & 0.528 \\
\hline 34 & Unclear instructions from contractors & 2.57 & 2.77 & 2.94 & 0.468 & 2.64 & 2.70 & 2.38 & 0.601 \\
\hline 35 & $\begin{array}{l}\text { Unclear instructions from owner } \\
\text { External Environment }\end{array}$ & 3.36 & 3.34 & 3.63 & 0.737 & 3.30 & 3.29 & 3.19 & 0.952 \\
\hline 36 & $\begin{array}{l}\text { Lack of anticipation for natural } \\
\text { conditions }\end{array}$ & 2.70 & 2.82 & 2.63 & 0.792 & 2.93 & 2.98 & 3.25 & 0.692 \\
\hline 37 & $\begin{array}{l}\text { Poor site conditions (water, electricity, } \\
\text { telephone) }\end{array}$ & 2.43 & 2.41 & 2.63 & 0.755 & 2.43 & 2.48 & 2.63 & 0.824 \\
\hline 38 & $\begin{array}{l}\text { Disturbance from surrounding } \\
\text { residents }\end{array}$ & 2.82 & 2.77 & 2.31 & 0.376 & 3.02 & 2.89 & 2.63 & 0.588 \\
\hline & Contract Administration & & & & & & & & \\
\hline 39 & Change in scope of work & 3.16 & 3.11 & 3.13 & 0.974 & 2.91 & 3.11 & 3.38 & 0.214 \\
\hline 40 & Poor documentation by contractors & 2.61 & 2.50 & 3.06 & 0.273 & 2.88 & 2.77 & 3.13 & 0.634 \\
\hline 41 & $\begin{array}{l}\text { Unclear scope of work on contract } \\
\text { documents (material specifications) }\end{array}$ & 3.07 & 3.18 & 2.44 & 0.123 & 3.11 & 3.02 & 2.50 & 0.797 \\
\hline
\end{tabular}

*) Factors with significant difference at $\alpha=5 \%$

\section{Research Method}

The identified factors were used for data collection which was carried out by distributing questionnaires to civil/general contractors for structural and finishing works and MEP contractors for MEP works. The targeted respondents were those who were working on high rise building projects located in Surabaya, where the researchers had access to distribute questionnaire.

\section{The Questionnaire}

The questionnaire was divided into three parts, in which the first part asked the respondents' personal data. The second part contained questions about the frequency and difficulty of each of the factors causing the rework. The scale used was a scale of one (1) to six (6). For the frequency part, the larger the scale the more frequent rework occurred due to these factors. Meanwhile, for the difficulty level of prevention, the larger the scale the more difficult it was to prevent the emergence of these factors.

Before distributing to respondents, the questionnaire was tested to a number of respondents. The purpose was to examine whether the items of the questionnaire (including the instructions) were clear and easily understood by the respondents. The questionnaire would be revised according to respondents' comments and inputs.

\section{Analyses of Frequency and Difficulty Level of Prevention}

Data from contractors would be processed using mean analysis to determine which factors often cause rework and are difficult to prevent. Anova analysis would then be carried out to determine whether there are differences between structural, finishing, and MEP works for the frequency and difficulty level of prevention.

In the anova analysis, the initial hypothesis used was that there was no difference between the mean values of structural, finishing, and MEP works (regarding to the frequency and difficulty level), with a significance value of $\alpha=5 \%$. If the $p$-value of the analysis result was less than or equal to 0.05 , it was concluded that there is a difference between these three works. The results from the anova test would be used to decide whether the mean values (of the frequency and level of difficulty) of the factors could be combined for the three construction works before conducting the importance performance analysis described below.

\section{Importance Performance Analysis}

The analysis used to determine the importance of the causal factors was importance performance analysis (IPA), which was carried out by combining the frequency and the difficulty level of prevention for each factor causing the rework. The factors causing 
the rework would be grouped into three levels of importance, namely high (1), medium (2), and low (3) importance.

The cutoff point used for the mean values of frequency and level of difficulty of prevention was the median value of the six scale described above, i.e. 3.5. The factor would enter into the high importance level group if all the mean values of the frequency and difficulty level of prevention were greater than 3.5. If only one of the mean values (frequency or level of difficulty) was greater than 3.5 then the factor would be grouped into medium importance. The importance of the factor would be low if all the mean values were less than 3.5.

\section{Results and Discussions}

From the 100 questionnaires distributed, the researcher could gather 72 questionnaires consisting of 56 respondents from general contractors and 16 respondents from MEP contractors. The general information of the respondents can be seen in Table 2

Table 2. General Information of the Respondents

\begin{tabular}{llrr}
\hline \multirow{2}{*}{ Item } & \multirow{2}{*}{ Distribution } & \multicolumn{2}{c}{ No of Respondents } \\
\cline { 3 - 4 } Sex & Male & Genera & MEP \\
\cline { 2 - 3 } Age & Female & 9 & 14 \\
& $20-30$ & 32 & 2 \\
Years of & $30-40$ & 15 & 10 \\
Experience & $>40$ & 9 & 4 \\
Position in & $5-10$ & 25 & 2 \\
Company & Top Manager & 14 & 10 \\
& Engineer & 17 & 2 \\
& PM & 18 & 4 \\
Education & Others & 4 & 0 \\
& High School & 32 & 7 \\
& Bachelor & 39 & 6 \\
& Master & 1 & 6 \\
& Others & 5 & 0 \\
\hline
\end{tabular}

Frequency of Factors Causing Rework on Structural, Finishing, and MEP Works

Table 1 shows the results of the frequency analysis of the factors causing the rework on the structural, finishing, and MEP works. In structural and finishing work, the design change is the most frequent factor causing rework with a mean value of 4.38 . This answer is in accordance with the previous research [6], where the design factor is the factor that most often causes rework. The factor of unclear detail design is also a factor that often occurs in structural and finishing works with a mean value of 4.09 and 4.14 , respectively.
Designs with lack of constructability aspects, design errors, and a designer lack of knowledge of construction materials are also perceived by general contractors as factors that often cause rework on projects. The occurrence of these factors can result in design changes previously described during project implementation.

Tight project schedule is the factor that most often causes rework on MEP works with a mean value of 3.75. One respondent of MEP contractors explained that they were often late in being appointed by the owner, but had to complete the work within the deadline of the general contractor's work. This made the schedule of the MEP work very tight that forced the workers work in a hurry and easily make mistakes in their works.

The factor of the number of subcontractors/Direct Contractors (DCs)/contractors involved in the project also frequently occurs, with mean values of 3.96 for structural work and 3.73 for finishing work. In general, to pursue their work schedule, subcontractors/DCs/contractors usually focus on their own jobs and pay less attention on the works of other contractors. This problem is getting worse if the work scope of each contractor are unclear, so that clashes between works often occur in the field, which in turn lead to the emergence of a rework.

The respondents point out that unclear instructions from the owner and designer consultant often occurred causing reworks on MEP works, with a mean value of 3.63. From the clarification of the respondent, the instructions here relate to the project owner's requests which often change as the project progresses, as well as the design-related instructions from the designer consultant.

\section{Difficulty Level of Prevention of Factors Causing Rework}

Table 1 shows the results of the analysis on the difficulty level of preventing the factors causing the rework. Design change is the most difficult factor to prevent in structural and finishing works, with mean values of 3.88 and 4.11. MEP contractors also deem this factor difficult to prevent with a mean value of 3.75 .

The unclear detail design is also a factor that is difficult to prevent in structural and finishing works with mean values of 3.68 and 3.88 respectively. This is because the general contractors surveyed were mostly not involved in the planning process. Generally, the types of contracts experienced by the respondents surveyed are traditional. Nevertheless, as a 
part of their quality management process, the contractors are expected to be proactive in reviewing the design before the construction works begin. They may discuss or send request for information (RFI) to the owner/consultants when detecting any mistakes in designs (such as unclear designs or design errors).

The MEP contractors state that lack of capital from the owner was the most difficult factor to prevent (mean value of 4.06). They further mention that when the owner does not have sufficient working capital, it will result in changes to the existing design.

It can be seen that in general the factors that have high level of difficulty in prevention in the three construction works are originated by consultants and owners, so the contractors perceive them difficult to control the emergence reworks caused by these factors.

Table 3. Importance Performance Analysis of Factors Causing Reworks (with no significant difference between Structural, Finishing and MEP works)

\begin{tabular}{|c|c|c|c|c|}
\hline No & Factors & Frequency & $\begin{array}{c}\text { Difficulty level } \\
\text { of prevention }\end{array}$ & $\begin{array}{c}\text { Importance } \\
\text { level }\end{array}$ \\
\hline & Design and documentation & & & \\
\hline 1 & Lack of consultant's knowledge of material character & 3.64 & 3.38 & 2 \\
\hline \multirow[t]{2}{*}{2} & Design error & 3.48 & 3.50 & 3 \\
\hline & Planning and scheduling & & & \\
\hline \multirow[t]{2}{*}{3} & Tight project schedule & 3.48 & 3.24 & 3 \\
\hline & Materials and equipment & & & \\
\hline 4 & Material sent incorrectly & 2.65 & 2.64 & 3 \\
\hline 5 & Late material & 3.23 & 3.01 & 3 \\
\hline 6 & Unavailable when needed & 2.89 & 2.70 & 3 \\
\hline \multirow[t]{2}{*}{7} & Material / equipment changes during construction & 3.17 & 3.05 & 3 \\
\hline & Human Resources & & & \\
\hline 8 & Lack of workers motivation & 2.72 & 2.80 & 3 \\
\hline 9 & Inexperienced workers & 2.73 & 2.87 & 3 \\
\hline 10 & Wrong work procedure & 2.80 & 2.93 & 3 \\
\hline \multirow[t]{2}{*}{11} & Worker's errors and omissions & 2.88 & 3.02 & 3 \\
\hline & Leadership and communication & & & \\
\hline 12 & $\begin{array}{l}\text { Ineffective communication between the supervisory consultant and the } \\
\text { contractor }\end{array}$ & 3.28 & 3.66 & 3 \\
\hline 13 & Ineffective communication between contractors and workers & 2.88 & 2.86 & 3 \\
\hline 14 & Poor coordination between contractors & 2.94 & 3.10 & 3 \\
\hline 15 & $\begin{array}{l}\text { The number of subcontractors / DCs / contractors involved in the } \\
\text { project }\end{array}$ & 3.76 & 3.49 & 2 \\
\hline 16 & Poor decision making process from contractors & 2.94 & 3.10 & 3 \\
\hline 17 & Poor decision making process from the owner & 3.26 & 3.48 & 3 \\
\hline 18 & Lack of field information & 3.05 & 2.93 & 3 \\
\hline 19 & Lack of contractor management from the project team & 2.81 & 2.77 & 3 \\
\hline 20 & Lack of owner role during construction & 2.95 & 2.90 & 3 \\
\hline \multirow[t]{2}{*}{21} & Lack of contractor QC commitment & 2.74 & 2.74 & 3 \\
\hline & Instructions and Inspections & & & \\
\hline 22 & Poor monitoring and control by contractor & 2.62 & 2.86 & 3 \\
\hline 23 & Poor monitoring and control by consultant & 3.04 & 3.14 & 3 \\
\hline 24 & Unclear instructions from the planning consultant & 3.34 & 3.20 & 3 \\
\hline 25 & Unclear instructions from contractors & 2.70 & 2.63 & 3 \\
\hline \multirow[t]{2}{*}{26} & Unclear instructions from owner & 3.38 & 3.28 & 3 \\
\hline & External Environment & & & \\
\hline 27 & Lack of anticipation for natural conditions & 2.74 & 2.99 & 3 \\
\hline 28 & Poor site conditions (water, electricity, telephone) & 2.45 & 2.48 & 3 \\
\hline \multirow[t]{2}{*}{29} & Disturbance from surrounding residents & 2.73 & 2.90 & 3 \\
\hline & Contract administration & & & \\
\hline 30 & Change in scope of work & 3.13 & 2.99 & 3 \\
\hline 31 & Poor documentation by contractors & 2.72 & 2.66 & 3 \\
\hline 32 & Unclear scope of work on contract documents (material specifications) & 3.04 & 3.06 & 3 \\
\hline
\end{tabular}




\section{Analysis of the Difference in Frequency and Difficulty of Prevention}

As shown in Table 1, in general there is no significant difference in the mean values of frequency and the difficulty level of prevention between structural, finishing, and MEP works. Only six factors were found to be significantly different on the frequency value test and four factors on the difficulty level value test ( $p$-value $\leq 0.05$ ). From the tests conducted, these differences lie in the MEP work when compared to the structural and finishing works. As a result, in total there are nine factors that are said to be significantly different resulted from these anova tests.

The mean values of the frequency and difficulty level of preventing the factors that were not significantly different were then combined between the structural, finishing, and MEP works to determine the importance level of each factor. Meanwhile, the factors that were found to be significantly different (in one or both tests), the analysis of the level of importance was made separately between MEP works and structural and finishing works.

\section{Importance Performance Analysis}

Table 3 shows the importance performance analysis of the factors causing rework which do not differ significantly between the structural, finishing, and MEP works. Two factors fall into the medium level of importance, namely the consultant's lack of knowledge about the character of the material and the number of subcontractors/DCs/contractors involved in the project, where these two factors have a high frequency mean value. Other factors fall into the low importance group.

Table 4. Importance Performance Analysis of Factors Causing Reworks in Structural and Finishing Works

\begin{tabular}{|c|c|c|c|c|}
\hline No & Factors & $\begin{array}{c}\text { Frequ- } \\
\text { ency }\end{array}$ & $\begin{array}{c}\text { Difficulty } \\
\text { level of } \\
\text { prevention }\end{array}$ & $\begin{array}{c}\text { Importance } \\
\text { level }\end{array}$ \\
\hline \multicolumn{5}{|c|}{ Design and documentation } \\
\hline 1 & Design changes & 4.38 & 3.99 & 1 \\
\hline 2 & $\begin{array}{l}\text { Unclear detail } \\
\text { drawings }\end{array}$ & 4.12 & 3.78 & 1 \\
\hline 3 & $\begin{array}{l}\text { Lack of constructability } \\
\text { aspects }\end{array}$ & 3.59 & 3.39 & 2 \\
\hline \multicolumn{5}{|c|}{ Planning and scheduling } \\
\hline 4 & $\begin{array}{l}\text { Lack of working capital } \\
\text { from owner }\end{array}$ & 2.97 & 3.06 & 3 \\
\hline 5 & $\begin{array}{l}\text { Change in project } \\
\text { function }\end{array}$ & 2.79 & 2.83 & 3 \\
\hline \multicolumn{5}{|c|}{ Materials and equipment } \\
\hline 6 & Defective material & 3.12 & 3.13 & 3 \\
\hline 7 & $\begin{array}{l}\text { Lack of adequate } \\
\text { equipment } \\
\text { Human Resources }\end{array}$ & 2.62 & 2.70 & 3 \\
\hline 8 & $\begin{array}{l}\text { Lack of training for } \\
\text { workers }\end{array}$ & 2.66 & 2.54 & 3 \\
\hline 9 & $\begin{array}{l}\text { The amount of } \\
\text { overtime work }\end{array}$ & 3.46 & 2.97 & 3 \\
\hline
\end{tabular}

Table 4 shows the IPA of factors that differ significantly based on the frequency or difficulty of preventing them in structural and finishing works, and Table 5 for MEP works. Design change factors and unclear detailed drawings are factors of high importance in structural and finishing works. Owners and consultants must pay more attention to these two design factors so that efforts to reduce rework on construction projects can be more effective.

The results of IPA of factors causing reworks in MEP works are shown in Table 5. Two factors have medium importance level and the rests are low importance. The two factors (i.e. design changes and lack of working capital from owner) are again beyond the control of the MEP contractors.

Table 5. Importance Performance Analysis of Factors Causing Reworks in MEP Works

\begin{tabular}{|c|c|c|c|c|}
\hline No & Factors & $\begin{array}{l}\text { Frequ- } \\
\text { ency }\end{array}$ & $\begin{array}{l}\text { Difficulty } \\
\text { level of } \\
\text { prevention }\end{array}$ & $\begin{array}{c}\text { Importance } \\
\text { level }\end{array}$ \\
\hline & \multicolumn{4}{|c|}{ Design and documentation } \\
\hline 1 & Design changes & 3.38 & 3.75 & 2 \\
\hline 2 & $\begin{array}{l}\text { Unclear detail } \\
\text { drawings }\end{array}$ & 2.88 & 4.06 & 3 \\
\hline 3 & $\begin{array}{l}\text { Lack of constructability } \\
\text { aspects }\end{array}$ & 3.00 & 2.56 & 3 \\
\hline 4 & $\begin{array}{l}\text { Planning and schedu } \\
\text { Lack of working capital } \\
\text { from owner }\end{array}$ & $\begin{array}{l}\text { ling } \\
1.75\end{array}$ & 2.63 & 2 \\
\hline 5 & $\begin{array}{l}\text { Change in project } \\
\text { function }\end{array}$ & 2.00 & 2.81 & 3 \\
\hline \multicolumn{5}{|c|}{ Materials and equipment } \\
\hline 6 & Defective material & 2.81 & 3.44 & 3 \\
\hline 7 & $\begin{array}{l}\text { Lack of adequate } \\
\text { equipment } \\
\text { Human Resources }\end{array}$ & 3.31 & 3.44 & 3 \\
\hline 8 & $\begin{array}{l}\text { Lack of training for } \\
\text { workers }\end{array}$ & 2.81 & 3.25 & 3 \\
\hline 9 & $\begin{array}{l}\text { The amount of } \\
\text { overtime work }\end{array}$ & 2.81 & 2.94 & 3 \\
\hline
\end{tabular}

\section{Conclusions and Recommendations}

The results showed that factors that most often cause rework in structural and finishing work are related to design and documentation factors, such as design changes, unclear detail design, lack of constructability aspects, consultant's lack of knowledge of construction materials, and design errors. General contractors (structure and finishing) also view these factors as being the most difficult to prevent their occurrence. Owners and consultants have more control to prevent or reduce the occurrence of these design factors.

In MEP works, tight schedule has the highest frequency value, followed by unclear instructions from 
the owner and consultant. Meanwhile, the factor causing the rework which had the highest level of difficulty in preventing MEP work was the lack of working capital from the owner.

The importance performance analyses show that most of the factors causing the rework have a medium or low level of importance. Only the factors of design change and unclear detail designs are of high importance. Owners and consultants have to pay more attention to these two factors so that efforts to reduce rework in structural and finishing works can be more effective.

The factors with medium and low importance are generally under the control of the contractor, where the contractors have a low level of difficulty to prevent their occurrence. It is suggested that the contractor should be able to prevent or reduce rework due to poor workmanship by implementing an integrated quality management program so that these factors can be avoided or eliminated.

Finally, the importance of the factors causing the rework on the structure, finishing, and MEP resulted in this study was limited on the views of the main contractor and the MEP contractor. It would be better if a more in-depth study was carried out based on the views of other parties such as the owner and consultants. It is intended that the level of importance of the factors causing the rework in the structural, finishing, and MEP works can be known more clearly from the views of various parties.

\section{References}

1. Burati, J.L., Farrington, J.J., and Ledbetter, J.B., Causes of Quality Deviations in Design and Construction, Journal of Construction Engineering and Management, 118, 1992, pp. 34-49.

2. Barber, P., Sheath, D., Tomkins, C., and Graves, A., The Cost of Quality Failures in Major Civil Engineering Projects, International Journal of Quality and Reliability Management, 17(4/5), 2000, pp. 479-492.

3. Love, P.E.D., Influence of Project Type and Procurement Method on Rework Cost in Building Construction Projects, Journal of Construction Engineering and Management, 128, 2002, pp. 1829.

4. Love, P.E.D., Edwards, D.J., Watson, H., and Davis, P., Rework in Civil Infrastructure Projects: Determination of Cost Predictor, Journal of Construction Engineering and Management, 136, 2010, pp. 275-282.
5. Zhang, D., Haas, C.T., Goodrum, P.M., Carlos, H.C., and Robin, G., Construction Small-Project Rework Reduction for Capital Facilities, Journal of Construction Engineering and Management, 138, 2012, pp. 1377-1385.

6. Andi., Winata, S., and Hendralim, Y., FaktorFaktor Penyebab Rework pada Pekerjaan Konstruksi, Civil Engineering Dimension, 7, 2005, pp. 22-29.

7. Sutrisna, N., Thanaya, I.N.A., and Sudipta, I.G.K. Analisis Rework pada Proyek Konstruksi Gedung di Kabupaten Badung, Jurnal Spektran, 1(2), 2013.

8. Herdianto, A., Tangjungsari, A.D.R., Hidayat, A., and Hatmoko, J.U.D., Evaluasi Pengerjaan Ulang (Rework) pada Proyek Konstruksi Gedung di Semarang, Jurnal Karya Teknik Sipil, 4(1), 2015, pp. 93-106.

9. Construction Industry Development Agency (CIDA), Measuring Up or Muddling Tough: Best Practice in the Australian Non-Residential Construction Industry, CIDA and Masters Builders Australia, Sydney, Australia, 1995.

10. Love, P.E.D., Holt, G.D., Shen, L.Y. Li, H., and Irani, Z., Using Systems Dynamics to Better Understand Change and Rework in Construction Project Management Systems. International Journal of Project Management, 20, 2002, pp. 425-436.

11. Rogge, D.F., Cogliser, C., Alaman, H., and McCormack, S., An Investigation of Field Rework in Industrial Construction, Construction Industry Institute, 2001, Austin, TX.

12. Taylor, T. and Ford, D. Managing Tipping Point Dynamics in Complex Construction Projects, Journal of Construction Engineering and Management, 134, 2008, pp. 421-431.

13. Fayek, A.R., Dissanayake, M., and Campero, O., Developing a Standard Methodology for Measuring and Classifying Construction Field Rework, Canadian Journal of Civil Engineering, 31, 2004, pp. 1077-1089.

14. Hwang, B., Thomas, S.R., Haas, C.T., and Caldas, C.H., Measuring The Impact of Rework on Construction Cost Performance, Journal of Construction Engineering and Management, 135, 2009, pp. 187-198.

15. Chundawan, E. and Alifen, R.S., Model Sumber dan Penyebab Rework pada Tahapan Proyek Konstruksi, Jurnal Dimensi Utama Teknik Sipil, $1,2014$.

16. Ye, G., Jin, Z., Xia, B., and Martin, Analyzing Causes for Reworks in Construction Projects in China, Journal of Construction Engineering and Management, 31, 2014. 